\title{
Human Rights Law (2018)
}

\author{
Marlies Hesselman*
}

There is no doubt that disasters carry important implications for the effective enjoyment of human rights, and that States have to take into account their obligations under international and regional human rights instruments in disaster management activities throughout the whole disaster management cycle. This section reviews how international and regional human rights bodies have made practical contributions to the clarification of relevant rights and obligations in 2018. As seen by the following examples, there is currently a real appetite, if not a proper momentum, for the adoption of interpretative statements and even legal instruments that consolidate clear, easily accessible and coherent protection of human rights in the sphere of environmental and disaster-related harms. ${ }^{1}$

UN Human Rights Law

$\mathbf{1 . 1}$

\section{CEDAW General Recommendation 37 on Gender-Related Aspects of} Disaster Risk Reduction in a Context of Climate Change

One of the most significant developments in international human rights law for 2018 has been the adoption of the first General Recommendation (GR) exclusively dedicated to human rights protection in disaster settings, by the monitoring committee for the Convention on the Elimination of All Forms of Discrimination Against Women (hereafter CEDAW for the Convention and CteeDAW for the Committee). ${ }^{2}$ GR 37 on the 'Gender-Related Dimensions of Disaster Risk Reduction in a Context of Climate Change' was adopted with the aim to clarify States' human rights obligations in relation to disaster risk reduction and climate change under the CEDAW, including for State periodic reporting purposes. It also seeks to foster 'coherence', 'accountability' and 'mutual reinforcement' of different related international agendas, including the UN

* Lecturer in International Law, University of Groningen.

1 This contribution does not touch upon the current discussions in the UN General Assembly regarding a new Global Pact for the Environment or binding instrument following the ILC Draft Articles on Protection of Persons in Event of Disasters, both of which would be likely to accord a central place to the protection of human rights, as these topics are covered in other sections of this Yearbook.

2 CEDAW, 'General Recommendation No. 37 on Gender-Related Dimensions of Disaster Risk Reduction in the Context of Climate Change' (7 February 2018) UN Doc CEDAW/C/GC/37. 
Sendai Framework on Disaster Risk Reduction, the UN Sustainable Development Goals, and the UN Framework Convention on Climate Change. ${ }^{3}$

GR 37 treats a wide range of substantive human rights and gender-related issues, also usefully discussed by Mayrhofer in this issue, ${ }^{4}$ including a number of more controversial international human rights law topics such as non-State actors' obligations and States' extra-territorial obligations. On the obligations of civil society organisations, CteeDAW notes that they 'have responsibilities to ensure that their activities in the fields of climate change and disaster risk reduction and management 'do no harm' to local populations' and that they 'should take steps to minimize the harm they may inadvertently be doing simply by being present and providing assistance. ${ }^{5}$

An important issue confronted by CteeDAW in determining the scope of application of GR 37 was to arrive at a suitable definition of 'disasters' and clarifying their linkage to climate change. CteeDAW's struggle is evident from the fact that the title of the document changed several times: from 'Disaster Risk Reduction and Climate Change' (at the General Day of Discussion in 2016) to 'Disaster Risk Reduction in a Changing Climate' (first draft of 2017) to 'Disaster Risk Reduction in a Context of Climate Change' (final draft of 2018). The Recommendation now clarifies that it does not purport to exhaustively cover all gender-related dimensions of climate change mitigation and adaptation, but also does not generally attempt 'to differentiate between disasters related to climate change and other disasters.' ${ }^{6}$ CteeDAWs definition of disasters is remarkably generous, and perhaps one of the widest in international law, for it includes:

all those events that are small-scale and large-scale, frequent and infrequent, sudden and slow-onset caused by natural or human-made hazards, as well as related environmental, technological and biological hazards and risks, mentioned in the Sendai Framework, as well as any other chemical, nuclear and biological hazards and risks. These hazards and risks also include testing and use of all types of weapons by State and non-State actors. ${ }^{7}$

3 Ibid., paras. 10-12.

4 Monika Mayrhofer, 'Gender (In)equality, Disaster and Human Rights - the CEDAw Committee and General Recommendation No. 37' in this issue, and also see Gabrielle Simm, 'Gender, Disasters and Law' in Susan Harris Rimmer and Kate Ogg (eds), Research Handbook on Feminist Engagement with International Law (Edward Elgar 2019) 118-133.

5 Ibid., para. $5^{0}$.

6 Ibid., para. 13 .

7 Ibid., para. 13 . 
Since its adoption, CteeDAW has consistently addressed recommendations on gender and disaster risk reduction (DRR) to States Parties during State reporting procedures. ${ }^{8}$ Some noticeable examples of Concluding Observations in support of the GR include CteeDAW's request to Palestine to submit more data on the number of rural women having 'benefited from the disaster risk reduction and insurance fund, ${ }^{9}$ or commending the Bahamas on carrying out a gender assessment following Hurricane Matthew and having women occupy senior positions at the National Emergency Management Agency. ${ }^{10}$ The most remarkable set of recommendations on GR 37 in 2018 is found in Saudi Arabia's Concluding Observations, which was asked to assess, 'under its extraterritorial obligations', the impact on Yemen's environment of its ongoing military operations in that country. ${ }^{11}$ This supposedly suggests that environmentally damaging extra-territorial military activities fall within the ambit of the Recommendation, and indeed, while GR 37 does not refer to armed conflicts as disasters situations as such, its definition of environmental, technological,

8 E.g. CEDAW, 'Concluding observations on the eighth periodic report of Australia' (20 July 2018) CEDAW/C/AUS/CO/9, paras. 29-30; CEDAW, 'Concluding observations on the sixth periodic report of Samoa' (14 November 2018) CEDAW/C/WSM/CO/6, paras. 41-42; CEDAW, 'Concluding observations on the combined second and third periodic reports of the Cook Islands' (25 July 2018) CEDAW/C/COK/CO/2-3, paras. 45-46; CEDAW, 'Concluding observations on the combined eighth and ninth periodic reports of the Lao People's Democratic Republic' (14 November 2018) CEDAW/C/LAO/CO/8-9, paras. 51-52; CEDAW, 'Concluding observations on the eighth periodic report of Cyprus' (25July 2018) CEDAW/ $\mathrm{C} / \mathrm{CYP} / \mathrm{CO} / 8$, para. 45; CEDAW, 'Concluding observations on the ninth periodic report of Mexico' (25 July 2018) CEDAW/C/MEX/CO/9, para. 44(d); CEDAW, 'Concluding observations on the fifth periodic report of Fiji' (14 March 2018) CEDAW/C/FIJ/CO/5, paras. 53-54; CEDAW, 'Concluding observations on the combined initial to third periodic reports of the Marshall Islands' (14 March 2018) CEDAW/C/MHL/CO/1-3, paras. 44-45; CEDAW, 'Concluding observations on the combined fourth to sixth periodic reports of Suriname' (14 March 2018) CEDAW/C/SUR/CO-4-6, paras. 42-43; CEDAW, 'Concluding observations on the eighth periodic report of Mauritius' (14 November 2018) CEDAW/C/MUS/CO/8, paras. $35^{-36}$.

9 CEDAW, Concluding Observations on State of Palestine (11 July 2018) CEDAW/C/PSE/CO/1, para. 43(c). Incidentally, this Observation was not linked to General Recommendation 37 specifically, but to General Recommendation 34 on Rural Women's Rights. The same applies to other observations in 2018, and follows the CteeDAWs practice pre-GR 37, e.g. CEDAW, 'Concluding observations on the sixth periodic report of the former Yugoslav Republic of Macedonia' (14 November 2018) CEDAW/C/MKD/CO/6, para. 42(d) or CEDAW, 'Concluding observations on the seventh periodic report of Chile' (14 March 2018) CEDAW/C/CHL/CO/7, paras. 42-43.

10 CEDAW, 'Concluding Observations on the sixth periodic report of the Bahamas' (9 November 2018) CEDAW/C/BHS/CO/6, paras. 47-48.

11 CEDAW, Concluding Observations on the combined third and fourth periodic reports of Saudi Arabia (18 March 2018) CEDAW/C/SAU/CO/3-4, para. 54 . 
biological, chemical and nuclear hazards and risks includes the 'use of all types of weapons by State and non-State actors.'.12

It will be interesting to see the further influence and development of GR 37 in the course of reporting and monitoring practices under CEDAW in coming years, as well as the manner in which GR 37 will influence gender-mainstreaming in other UN human rights bodies' work on disaster-related aspects, or in relevant disaster management activity at national, regional or international level (see e.g. also developments in ASEAN below).

\subsection{Human Rights Committee General Comment on the Right to Life}

Also clarifying the applicability of States' human rights obligations in disaster settings is the long-awaited General Comment 36 by the Human Rights Committee on the right to life, replacing its former comment on the matter from the 1980 . $^{13}$ As anticipated, the Human Rights Committee clarifies a broad range of positive obligations for the protection of the right to life, including as relevant to disaster settings. Comments on DRR and disaster response are particularly included in a paragraph on the 'duty to protect life', which according to the $\mathrm{Hu}$ man Rights Committee gives rise to obligations to take appropriate measures 'to address the general conditions in society that may give rise to direct threats to life or prevent individuals from enjoying their right to life with dignity'.14 Such measures include the development of contingency and disaster management plans designed to increase preparedness and disaster response. In addition, the Committee calls for measures to ensure that individuals have access without delay 'to essential goods and services such as food, water, shelter, health-care, electricity and sanitation' and asks States to bolster effective emergency services in the area of health and emergency response operations (including fire-fighters, ambulances and police forces) to ensure that the right can be effectively protected..$^{15}$

The Human Rights Committee also addresses the evolutive interpretation of the right to life since the 1980 s by observing that 'environmental degradation, climate change and unsustainable development' are now amongst 'the most pressing and serious threats' to present and future generations' ability to enjoy the right to life. ${ }^{16}$ The Committee emphasizes the mutual supportiveness

\footnotetext{
12 Ibid., para. 13.

13 CCPR, 'General Comment No. 36 (2018) on Article 6 of the International Covenant on Civil and Political Rights, on the Right to Life' (30 October 2018) UN Doc CCPR/C/GC/36, para. 1 .

14 Ibid., para. 26.

15 Ibid., para. 26.

16 Ibid., para. 62.
} 
of international environmental law and human rights law, and provides that states have to take measures that preserve and protect the environment 'against harm, pollution and climate change caused by public and private actors', including through:

- developing and implementing substantive environmental standards;

- conducting environmental impact assessments;

- consulting with relevant States about activities likely to have a significant impact on the environment;

- providing notification to other States concerned about 'natural' disasters and emergencies and to cooperate with them;

- providing appropriate access to information on environmental hazards;

- paying due regard to the precautionary approach.

The Committee includes many references to legal instruments and interpretations of other bodies, thereby consolidating and confirming the converging interpretations on this topic across UN and regional (human rights) systems. The General Comment is an important and topical contribution to the field of human rights, environment, climate change and disasters.

\subsection{UN Framework Principles on Human Rights and the Environment}

In January 2018, UN Special Rapporteur on Human Rights and the Environment John Knox published his Framework Principles on Human Rights and the Environment intended to 'set out basic obligations of States under human rights law as they relate to the enjoyment of a safe, clean, healthy and sustainable environment'. ${ }^{17}$ The principles were drawn from relevant treaties and binding and non-binding decisions from human rights bodies, although Knox acknowledges that 'not all States have formally accepted all of these norms'. Considering the great coherence found in the interpretations of relevant provisions across bodies, Knox believes however, that States should accept the framework principles 'as a reflection of actual or emerging international human rights law', and 'at a bare minimum (...) as best practices that they should move to adopt as expeditiously as possible'.18 The Framework sets out the converging uniformity and certainty on environmental rights and obligations, but while providing a sturdy basis for understanding the relationship between the environment and human rights fields, it is in 'no sense the final word'. In fact, according to Knox there are still 'countless facets' that have to be explored and

\footnotetext{
17 HR Council, 'Report of the Special Rapporteur on the issue of human rights obligations relating to the enjoyment of a safe, clean, healthy and sustainable environment' (24 January 2018) UN Doc A/HRC/37/59.

18 Ibid., para. 9 .
} 
clarified as part of the mandate, and the field will likely 'continue to develop and evolve for many years to come. 19

Framework Principle 14 is most explicitly relevant for our present purposes, since it articulates the obligation to take 'additional measures' to protect those most vulnerable to environmental harm based on 'their needs, risks and capacities'. This includes, according to the commentaries, protection for persons with disabilities in 'natural disasters and extreme weather' settings, for such persons may struggle to receive emergency information in accessible formats, or access means of transport, shelter and relief. ${ }^{20}$ The commentary additionally mentions that disasters can exacerbate vulnerabilities and lead to additional human rights violation and abuse when they lead to displacement, thereby bringing in the aspect of disaster-related displacement. ${ }^{21}$

Finally, Framework Principles 6, 7, 9 and 10 include a range of procedural human rights obligations which are relevant to disaster settings as well. Inspired by the Aarhus Convention and in line with the new Escazú Agreement in Latin-America, these principles endorse access to environmental information and the immediate dissemination of information in case of 'imminent threats to human health or life. ${ }^{22}$

\subsection{Report of the Special Rapporteur on the Right to Food in the Context of Natural Disasters}

In January 2018, the UN Special Rapporteur on the Right to Food also released her first annual thematic report on the right to food and disasters, following similar thematic reports by other Special Rapporteurs in recent years (e.g. rapporteurs on housing and internally displaced persons). ${ }^{23}$ This report discusses country-specific examples on the implementation of the right to food in disaster settings, with the aim of contextualizing the direct and indirect impacts of disasters on the right to food and people's livelihoods, and explaining how hunger is caused by disasters.

In this context, Special Rapporteur Hilal Elver underscores both the importance of moving beyond voluntarists perspectives on food aid and the need to

\footnotetext{
$19 \quad$ Ibid., paras. 9-10, 63, 78.

$20 \quad$ Ibid., paras, $40-41(\mathrm{f})$.

21 Ibid., para. 41(h); See also Matthew Scott, 'Migration/Refugee Law', in this issue.

22 See ibid., Framework Principles 6, 7, 9 10, see Marlies Hesselman, 'International Environmental Law', and Silvia Venier, 'A Right to Information Relevant to Disaster Situations: Broadening the Concept beyond Early Warning and Addressing the Challenges Posed by Information and Communication Technologies', in this issue.

23 HR Council, 'Report of the Special Rapporteur on the Right to Food' (25 January 2018) UN Doc A/HRC/37/61.
} 
ensure better 'convergence between emergency food aid, food assistance and development cooperation': specifically, she recommends that States will negotiate 'a comprehensive, multilateral treaty of general application' on disaster assistance, which ties in with comments made above, and with current discussions in the UN General Assembly on the desirability of drafting a legal instrument based on the ILC's Draft Articles on Protection of Persons in Event of Disasters. ${ }^{24}$ Elver also includes a range of specific recommendations on the contents of such a possible instrument, and additionally recommends the Committee on Economic, Social and Cultural Rights to prepare a General Comment on the human rights remedies that are open to persons in disaster and post-disaster situations, as well as on the obligations of States and international communities to take preventive measures. ${ }^{25}$

The rich and thoughtful report contains many interesting observations on human rights and disasters generally, and on the right to food and disasters specifically, which cannot all be repeated here, but as a final observation, the Rapporteur usefully outlines some of the applicable law in this field, including the FAO Food Assistance Convention and related Voluntary Guidelines, ${ }^{26}$ and she stresses that the right to food in disaster contexts can be usefully seen as a collective right informing action on securing 'food sovereignty' for (vulnerable) affected populations. ${ }^{27}$

\subsection{Communications on Disasters by Special Procedures}

UN Special Procedures of the Human Rights Council regularly engage in communications procedures with States and non-State actors based on allegations of human rights violations received by the public. The procedures tend to be short and fairly formal, but often contain a wealth of information about law and facts as applicable to specific disaster settings. In 2018, two communications disasters were started and completed. ${ }^{28}$

\footnotetext{
24 Ibid., para. 10.

25 Ibid., paras. 112-113.

$26 \quad$ Ibid., paras. 88-97.

27 Ibid., paras. 109-111.

28 These communications and relevant document are listed in: HR Council, 'Communications Report of Special Procedures - Communications sent, 1 June to 30 November 2018; Replies received, 1 August 2018 to 31 January 2019' (12 February 2019) UN Doc A/HRC/40/79; HR Council, 'Communications Report of Special Procedures - Communications sent, 1 December 2018 to 28 February 2019; Replies received, 1 February to 30 April 2019' (17 June 2019) UN Doc A/HRC/41/56; The relevant documents related to each communication are also retrievable via the Special Procedures' communications portal by searching for 'disasters' or the following document numbers: Brazil (5 September 2018) BRA 11/2018; Australia (17 October 2018) AUS 4/2018; Samarco Mining S.A., Vale S.A. and BHP Billiton
} 
The first concerns the aftermath of the Fukushima disaster in Japan, and particular raised issues with the evacuation and resettlement of (vulnerable) evacuees, who the Rapporteurs classify as internally displaced persons. ${ }^{29}$ The second communication concerned the alleged continued adverse human rights impacts' in the Doce River basin as a result of the Samarco mining disaster that took place in Brazil in 2015. In the latter instance, letters were sent to Australia, Brazil and the three involved companies. The Special Procedures questioned Brazil and the companies largely on the various remedies put in place for victims after the disaster, including in the area of health and resettlement, and in particular whether 'robust assessments of the socio-environmental and socio-economic damages, including health consequences' were made, and whether the population had been sufficiently involved in the design of postdisaster remedies and agreements. ${ }^{30}$ Australia was asked to provide information on its measures to protect people against human rights abuse by business enterprises, including B HP Billiton, domiciled in its territory, and what it does to ensure that such enterprises 'conduct effective human rights due diligence to identify, prevent, mitigate and account for how they address their impacts on human rights throughout their operation, as set forth by the UN Guiding Principles on Business and Human Rights'. ${ }^{31}$ Each of the parties, Japan, Brazil, Australia and the companies, responded to the allegations shortly thereafter.

After the landmark Advisory Opinion on the Environment and Human Rights delivered by the Inter-American Court of Human Rights (IACtHR) on 15 November 2017, which included various important references to disasters, ${ }^{32}$ the

(17 October 2019) отн 56/2018, отн 57/2018, отн 58/2018; Japan (5 September 2018) JPN 6/2018. See <https://spcommreports.ohchr.org/>, last accessed (as any subsequent URL) on 30 June 2019.

29 See Communication to Japan (5 September 2018) JPN 6/2018, and extensive reply of the government of 5 November 2018.

30 See Communication to Brazil (5 September 2018) B RA 11/2018.

31 See Communication to Australia (17 October 2018) AUS 4/2018.

32 IACtHR, Advisory Opinion OC-23/17 as Requested by the Republic of Colombia, 'The Environment and Human Rights' (15 November 2017) IACtHR Ser A No 23, e.g. paras. 58, 67, 171-173, 190-196, 210, 223, 242 and related footnotes. 
adoption of the Escazú Regional Agreement on Access to Information, Public Participation and Justice in Environmental Matters in Latin America and the Caribbean by the UN Economic Commission for Latin America and the Caribbean on 4 March 2018 is another significant development for the region. ${ }^{33}$ This Yearbook's section on international environmental law discusses the Agreement further, ${ }^{34}$ but article 4(1) is worthwhile to mention here from a human rights perspective: 'Each Party shall guarantee the right of every person to live in a healthy environment and any other universally-recognized human right related to the present Agreement'. Once the Agreement enters into force after eleven ratifications, it will be interesting to see whether this provision generates specific obligations for Parties alongside other operative provisions - for example in light of the IACtHR Opinion. ${ }^{35}$

ASEAN Intergovernmental Commission on Human Rights' Thematic

\section{Study on Women in Natural Disasters}

In 2018, the ASEAN's Intergovernmental Commission on Human Rights Commission (AICHR) adopted its first thematic study on women's rights in natural disasters. ${ }^{36}$ The study is a valuable resource document amply outlining applicable international and ASEAN frameworks, and containing many details and country studies in relation to obstacles and opportunities for gendermainstreaming. It also concludes that 'certain issues still remain in the normconstruction stage' of integrating gender-approaches in regional disaster response strategies, and that discursive practices on gender in institutional settings are weak. ${ }^{37}$

33 Regional Agreement on Access to Information, Public Participation and Justice in Environmental Matters, Escazú, 4 March 2018, arts. 5 and 6.

34 See Marlies Hesselman, 'International Environmental Law', in this issue.

35 Eszacú Agreement (n. 33) arts. 4(1), 22. At the time of writing there are 16 signatures and 1 ratification.

36 For an overview of regional human rights regimes (Europe, American, African, Arab, Islamic and ASEAN) and their application to disaster settings, see: Marlies Hesselman, 'Regional Human Rights Regimes and Humanitarian Obligations of States in the Event of Disaster' in Zwitter et al (eds), Humanitarian Action: Global, Regional and Domestic Legal Responses to Local Challenges (CUP 2014) 202-227.

37 Carmel Abao et al, 'Women in Natural Disasters: Indicative Findings in Unraveling Gender in Institutional Responses: An ASEAN Intergovernmental Commission on Human Rights (AICHR) Thematic Study' (ASEAN 2018), available at <https://asean.org/aichr-the matic-study-women-natural-disasters-indicative-findings-unraveling-gender-institutionalresponses/>; AICHR, Annual Report 2018 (adopted 31 July 2018) 3-4, available at <https:// aichr.org/aichr-annual-report-2018/>. 
As an outcome, the study recommends that ASEAN members adopt an ASEAN Resolution on the 'integration of gender approaches in disaster risk reduction, climate change adaptation, sustainable development, and national security frameworks', create a Regional Technical Working Group on Women in Natural Disasters, improve cooperation between various ASEAN human rights and disaster management bodies, and draft a Regional Action Plan on Women in Natural Disasters which can function as a regional policy guide. ${ }^{38}$

In June 2018, the ASEAN Committee on Disaster Management agreed to further mainstream gender in (regional) disaster management strategies. ${ }^{39}$ Clearly, the AIHRC's study can serve as a first entry point for such efforts.

\subsection{Disasters in the African, Arab and Islamic Human Rights Systems}

Developments on human rights and disasters in Asian, African, Arab and Islamic human rights systems are not often explored in literature, although they do occur - in limited sense - in practice.

The Independent Permanent Commission on Human Rights of the Organization of the Islamic Conference (OIC), established to monitor human rights commitments under the 2008 oIC Charter and related oIC human rights instruments, for example endorsed the need to protect children's rights in disaster settings after a thematic day on the Convention on the Rights of Children in Islam, ${ }^{40}$ and discussed the effects of 'natural disasters, ecological and environmental degradation' on displacement during a thematic discussion day on migration in the region. The outcome document of the latter meeting emphasizes the 'risks, vulnerabilities and exploitations' faced by migrants 'during the entire cycle of migration from origin to destination. It additionally notes that OIC countries currently are responsible for the majority of refugee and displaced persons, both as countries of origin and as host countries. IOc parties are urged

$38 \quad$ Ibid., 131-133.

39 See press release ASEAN, 'ASEAN to Mainstream Gender Perspective in Disaster Management Strategies (29 June 2018), available at $<$ https://asean.org/asean-mainstream-genderperspective-disaster-management-strategies/?highlight=disasters\%202018 $>$. See further on the work of ASEAN bodies' work on disasters, Tokunaga Emika, 'Asia', in this issue.

40 OIC-IPHRC, 'Outcome Document of Thematic Debate on "Revisiting the oic Covenant on the Rights of Child in Islam to Reinforce the Rights of Children in Member States"' (13th Session of the OIC-IPHRC on 19 April 2019), available at <https://www.oiciphrc.org/ en/data/docs/session_reports/13th/Outcome\%2oDocument\%20\%2ofor\%2013th\%20 \%20Session.pdf>; OIC-IPHRC, 'Outcome Document of Thematic Debate on "Protecting and Promoting Rights of Children During Situations of Armed Conflict, Foreign Occupation, Emergencies an Disasters"' (1oth Session of the OIC-IPCHR on 1 December 2016), available at <https://www.oic-iphrc.org/en/data/docs/session_reports/1oth/1oth_out come_en.pdf $>$. 
to uphold the human rights of displaced persons on their territories, including per IOC human rights instruments. ${ }^{41}$

Second, disasters were touched upon in a range of State reports under periodic review with the African Commission on Human and Peoples Rights in 2018. Togo for example discussed its disaster risk reduction and civil protection activities under the right to liberty and security of the person, and the right to a general satisfactory environment in the Banjul Charter and its Maputo Protocol on women's rights. ${ }^{42}$ Lesotho and Nigeria both identified disasters as a complicating factor to the protection of the right to health. ${ }^{43}$ Unfortunately, the African Commission does not regularly publish concluding observations after reporting procedures, impairing the clarification of specific obligations under relevant African human rights instruments.

Finally, during the Africa-Arab Platform on Disaster Risk Reduction, held in Tunisia in October 2018, both regions committed to collaborate to:

[e]nable the meaningful participation and uphold the human rights of women and girls, children and youth, older persons, persons with disabilities, displaced and migrant populations, and those in vulnerable situations such as the poor and marginalized, in disaster risk reduction and development planning and practice. ${ }^{44}$

41 OIC-IPhrc, 'Session Outcome Document of Thematic Debate on "Promoting and Protecting the Rights of Refugees and Migrants; An Islamic and International Human Rights Obligation"' (14th Session of the IOC-IPHRC on 6 December 2018) 2, 4, available at https:// www.oic-iphrc.org/en/data/docs/session_reports/14th/14th\%20Session\%20Outcome $\%$ 2oDocument_EV.pdf.

42 See Republic of Togo, 'Periodic Report 6, 7, 8: 2011-2016' (considered at the 62nd Ordinary Session of the African Commission on Human and Peoples' Rights, 25 April - 9 May 2018) 22, 25-26, 132, 135, 175-176, available at http://www.achpr.org/states/togo/reports/8th $-2011-2016 /$.

43 The Kingdom of Lesotho, 'Periodic Report Combined 2nd to 8th, 2001-2017' (considered at the 62nd Ordinary Session of the African Commission on Human and Peoples' Rights, 25 April - 9 May 2018) para. 176, available at http://www.achpr.org/states/lesotho/ reports/6th-to-8th-2001-2017/; Federal Republic of Nigeria, '6th Periodic Report, 2015-2016' (considered at the 62nd Ordinary Session of the African Commission on Human and Peoples' Rights, 25 April - 9 May 2018), available at http://www.achpr.org/states/nigeria/ reports/6th-2015-2016/.

44 See Africa-Arab Platform on Disaster Risk Reduction, 'Communique of the Chair on Africa-Arab Cooperation on Disaster Risk Reduction, Tunis, Tunisia' (31 October 2018), available at https://www.preventionweb.net/files/62493_communique.pdf. See also: Nicholas Wasonga Orago, 'Africa and MEnA Region', in this issue. 